\title{
NOTES
}

\section{NONCONFORMING USES: A RATIONALE AND AN APPROACH}

One of the principal obstacles to a modern city's attainment of an ideally planned community is a legislative or judicial requirement that uses of property in existence at the time of the enactment or amendment of a zoning ordinance, which do not conform to the newly prescribed uses of the area, may not be forced to discontinue. Popularly labeled, this is the problem of the existing nonconforming use. This Note will first seek to define by case law and statute the phrase "existing nonconforming use" and describe the privileges extended to such uses. Then a rationale for the protection of existing uses can be submitted and the present law criticized in the light of the rationale.

\section{The Problem and Its Sources}

The power of a city to zone is an aspect of the state's police power and must be conferred by the state through an enabling statute. ${ }^{1}$ A typical zoning ordinance classifies each portion of the urban area into one of several zones ranging from "Class A residential" to "least restricted" and prohibits the establishment of a particular use in an area zoned for uses of a higher classification. ${ }^{2}$ However, it may be possible for some common uses of property to be excluded altogether. ${ }^{3}$ The classification of an area must bear a reasonable relation to the actual composition of the neighborhood at the time of the enactment of the ordinance, ${ }^{4}$ although the mere

1. See Durkin Lumber Co. v. Fitzsimmons, 106 N.J.L. 183, 187-88, 147 Atl. 555,557 (1929).

2. The Philadelphia zoning ordinance, for instance, contains the following general classifications : residential, commercial, industrial, least restricted, and park districts. The residential and commercial have several subclassifications each. PHILAdELPHIA Zoning Ordinance \$\$ 5-25, Ordinances of THE CTty of PhILAdeiphia 276-334 (1933), as amended through 1952. While most ordinances allow a higher use to locate in an area zoned for a lower classification, it can be argued that such a practice encourages the development of slums and should be prohibited.

3. See Duffcon Concrete Products, Inc. v. Cresskill, 1 N.J. 509, 64 A.2d 347 (1949). Here the town was permitted to prohibit completely manufacturing businesses that used more than one horse power mechanical power, businesses that sold produce other than at retail, businesses that furnished services for other than residents, or businesses employing more than five persons. The court took notice of a nearby area peculiarly adapted to industrial development and sufficiently large to accommodate such development for years to come.

4. Forbes v. Hubbard, 348 IIl. 166, 180 N.E. 767 (1932) (where highest use of property is commercial, unreasonable to restrict use to single family dwellings); Sigretto v. Board of Adjus't of Rutherford, 134 N.J.L. 587, 50 A.2d 492 (Sup. Ct. 1946) (unreasonable to restrict to residences land in an area unsuited to residential purposes); Tews v. Woolhiser, 352 I11. 212, 185 N.E. 827 (1933) (unreasonable to zone as residential a triangle surrounded by a commercial district). 
fact that a sparsely settled area is adaptable for industrial use will not prevent the city from zoning it as residential. ${ }^{5}$ An individual landowner may be able to attack the ordinance successfully on the ground that his property should have been classified with a neighboring area, ${ }^{6}$ or that the effect of the zoning law has been to render his property worthless. ${ }^{7}$ In spite of these general limitations, however, uses that do not conform to the applicable zoning classification are bound to exist, especially in older and more fully developed communities.

The rules of nonconformity typically come into operation when a building is in use for a specific purpose at the time of the enactment of the zoning restriction outlawing such use. In Jones v. City of Los Angeles $^{8}$ four mental hospitals were located in an area at the time it was decreed residential. The court held that although hospitals are proper subjects of exclusion from residential areas, only extraordinary public necessity could justify zoning that would require established uses to change without compensation. ${ }^{9}$ Zoning here was distinguished from nuisance law in that the former is not limited to the control of harmful uses. Because of this distinction, the court said that zoning must not be allowed to have retroactive effect or be so drastic as the law of nuisances. ${ }^{10}$ This doctrine has found substantial support in other jurisdictions on the general theory that "Zoning seeks to stabilize and protect and not to destroy." 11 Recently the New York Court of Appeals clarified the doctrine by saying that the property owner is protected when his interest is too substantial to justify deprivation in the light of the objectives to be achieved by enforcement of the zoning provision. Since a regulation which requires cessation of an already existing use will almost always impose a substantial loss and hardship, there has developed a doctrine of protection of nonconforming uses generally. The New York court held that here, however, since termination of the particular nonconforming use did not render valueless any substantial improvements or well-established businesses, the municipality was not required to permit the use to continue. ${ }^{12}$

Basically the nonconforming use receives its protection from the state and federal constitutions which prohibit the deprivation of property without due process of law. In addition, some states and municipalities, apparently with a desire to calm the fears of property owners, ${ }^{13}$ have included in their zoning legislation specific provisions forbidding the destruction of

5. See Anderson v. Jester, 206 Iowa 452, 457, 221 N.W. 354, 357 (1928).

6. Mehl v. Stegner, 38 Ohio App. 416, 175 N.E. 172 (1930).

7. Eaton v. Sweeny, 257 N.Y. 176, 177 N.E. 412 (1931). Compare Sawdey Liquor License Case, $369 \mathrm{~Pa}$. 19, 85 A.2d 28 (1951) (hotel, which was permissible use under zoning law, could not be forbidden by zoning law to serve liquor).

8. 211 Cal. 304, 295 Pac. 14 (1930).

9. Id. at $314,295 \mathrm{Pac}$. at 19.

10. Id. at 316,295 Pac. at 20.

11. BAssett, Zoning 105 (1936). See also id., at $105 \mathrm{n} .1$ (cases cited).

12. People v. Miller, 304 N.Y. 105, 106 N.E.2d 34 (1952).

13. See Bassett, Zoning 113 (1936). 
nonconforming uses. $^{14}$ In the absence of such legislation, however, it is the state courts' interpretation of due process which forbids forced discontinuance; up to now there has been no United States Supreme Court decision concerning nonconforming uses under a general zoning enactment. ${ }^{15}$

Neither the due process clauses nor the legislative restrictions demand the permissive continuance of all nonconforming uses. Eminent domain and the law of nuisances stand as effective, but limited, tools for the elimination of undesirable uses of property. Eminent domain provides the basis for slum clearance programs in which a municipality condemns an entire slum or blighted area, compensates the landowners, clears the area and constructs or authorizes the construction of housing or commercial developments. One limitation on the further exercise of this power is a constitutional requirement that the purchase must be for a public use. ${ }^{18}$ Although at least one court has found sufficient public use in preventing the erection of a nonconforming building in a residential zone, ${ }^{17}$ it is extremely doubtful that the power of eminent domain could be used to destroy many existing nonconforming uses. Even aside from the constitutional question, extensive use of eminent domain is prohibited by the administrative difficulties involved in carrying out the necessary valuation procedures and the high cost necessary to reimburse property owners. ${ }^{18}$ Yet it is important not to overlook the possibility of utilizing this power where the circumstances are such as to satisfy the constitutional requirements and justify the expense. ${ }^{19}$

The law of nuisances is also closely related to zoning and has proved helpful in eliminating certain uses. If a use can be declared a nuisance it may be forced out of existence immediately. Although some courts limit the legislature to destroying only those uses which constitute com-

14. E.g., Mass. Ann. Laws c. 40, 26 (1952) ; N.J. Stat. Ann. tit. 40, \$55-48 (1940); Philadelphta Zoning Ordinance \$4(1), (2), Ordinances of the City of Philadelphia 274 (1933), as amended through 1952.

15. Cf. Dobbins v. Los Angeles, 195 U.S. 223 (1904) (amendment to an ordinance limiting the location of gas works held an invalid exercise of the police power as applied to a plant in the process of construction prior to the amendment).

16. Much confusion has resulted from the constitutional requirement that taking for eminent domain be for a "public use" which narrowly defined means "use by the public" or broadly defined means "public advantage." The opinions have failed to indicate clearly whether the public use results from the removal of a slum area or the construction of much needed housing. See 101 U. of PA. L. REV. 1246 (1953).

The expenditure of public funds to control the use of property is an aspect of Great Britain's Town and Country Planning Act, 1947, 10 \& 11 GEo. 6, c. 51. See Watts, Book Review, 65 HARV. L. REv. 902, 904-5 (1952).

17. State ex rel. Twin City Building and Investment Co. v. Houghton, 144 Minn. 1, 176 N.W. 159 (1920).

18. See Bassetr, Zoning 27 (1936).

19. In 1947 a Michigan statute authorized cities and villages to acquire "by purchase, condemnation or otherwise private property for the removal of nonconforming uses and structures." Mich. STAT. ANN. c. $54 \$ 5.2933(1)(1949)$. 
mon law nuisances, ${ }^{20}$ the better authority allows the lawmakers to expand the nuisance category. ${ }^{21}$ However, even the latter cases seem to be restricted principally to uses causing "a tangible and material interference with the property or personal well being of others, and likely to constitute or become... common law [nuisances]." 22 Probably nuisance law could not be brought into operation when the sole purpose of the prohibition is to achieve uniformity in the neighborhood.23 Furthermore, as will be developed later, it may be quite undesirable and, for practical purposes, impossible to effect immediate destruction of all nonconforming uses.

In short, in spite of the existence of eminent domain and nuisance law, most nonconforming uses must be dealt with under the law of zoning. It is important to note, however, that since eminent domain and nuisance law are available, the uses with which zoning is concerned are the less undesirable ones.

The early history of zoning was marked not only by general acceptance of the theory that to oust existing nonconforming uses would be unreasonable because of retroactivity, but also by the absence of any counterbalancing incentive to attack continuance of the uses. The nonconforming use was not recognized as a potential source of great difficulty; it was thought that nonconformers would be few in number and that time, aided by restrictions on expansion, would repair the omissions. ${ }^{24}$ Furthermore, those uses that were particularly annoying would be subject to nuisance law and possibly extinguished thereunder. ${ }^{25}$ The fact is, however, that the nonconforming uses, often granted by law a monopolistic position in their neighborhood, have become more firmly entrenched with the passage of time. ${ }^{28}$ Because of this development it may be well to reconsider the basic doctrine of existing nonconforming uses with an eye towards either justifying the doctrine, or limiting the incidence (and hastening the elimination) of the uses.

\section{The Law of Nonconforming Uses}

Defining the Use.-The foregoing discussion has assumed a broad definition of the existing nonconforming use. But there are situations where intricate problems arise as to what is or is not an existing use. If the use involves a building, the zoning law exemption applies only while the

20. E.g., Bielecki v. Port Arthur, 12 S.W.2d 976 (Tex. Comm. App. 1929); Manos v. Seattle, 173 Wash. 662, 667, 24 P.2d 91, 92 (1933); cases collected in Noel, Retroactive Zoning and Nuisances, 41 CoL. L. Rev. 457, 461 (1941).

21. E.g., Hadacheck v. Sebastian, 239 U.S. 394 (1915).

22. Noel, sipra note 15 , at 467 .

23. Id. at 467-70. The author indicates that there are a few decisions in which enterprises causing only intangible aesthetic annoyances have been held to constitute common law nuisances but concludes that prevailing judicial opinion is probably to the contrary.

24. Bassetr, Zoning 105 (1936).

25. Ibid.

26. See Note, 35 VA. L. REv. 348, 352-3 (1949). 
building is in the same location as it was when the ordinance was passed. ${ }^{27}$ Although "existing" ordinarily means existing at the effective date of the ordinance, ${ }^{28}$ uses that are seasonal or have been temporarily discontinued are not precluded. ${ }^{29}$ A use must be what is "customarily and habitually done" on the premises ${ }^{30}$ and thus cannot be established by occasional acts on the land. ${ }^{31}$ The mere fact that land has been platted and subdivided in preparation for construction prior to the ordinance probably will not prevent the operation of zoning restrictions on the parcels. ${ }^{32}$ Existence of one nonconforming use cannot be established by use for a significantly different nonconforming purpose ${ }^{33}$ for instance, permissive continuance of a nonconforming use for the manufacture of one item does not necessarily mean that a use may be established for the manufacture, likewise nonconforming, of a different article. ${ }^{34}$ On the other hand, where an investment in buildings is at stake, a court may be unwilling to restrict a use to the specific activity in existence at the time of the zoning enactment. ${ }^{35}$ Some ordinances permit a holder of a nonconforming use to change his use to one of the same or a higher zoning classification. This encourages property owners to change their nonconforming use as soon as it is economically feasible to do so. $^{36}$

The greatest difficulty in defining existing uses arises in determining what acts in connection with a use must have been performed prior to the effectiveness of the ordinance in order to establish the use. Of course,

27. Bianchi v. Commissioner of Public Bldgs., 279 Mass. 136, 181 N.E. 120 (1932) (sought to move building from one location to another).

28. See Fortunato v. Coral Gables, 47 So.2d 321, 322-3 (Fla. 1950).

29. Civic Ass'n of Dearborn v. Horowitz, 318 Mich. 333, 28 N.W.2d 97 (1947) (carnival); Adams v. Kalamazoo Ice \& Fuel Co., 245 Mich. 261, 222 N.W. 86 (1928) (ice house).

30. Durning v. Summerfield, 314 Ky. 318, 322, 235 S.W.2d 761, 763 (1951).

31. Ibid. (use by small carnivals for a total of 17 days in 10 years does not establish existing use); Baltimore v. Shapiro, 187 Md. 623, 51 A.2d 273 (1947) (dismantling cars on several occasions does not establish a use).

32. See Bubis v. Nashville, 174 Tenn. 134, 124 S.W.2d 238 (1939). In this type situation there was apparently no plea of nonconforming use although the court held the facts sufficient to support the grant of a variance.

33. E.g., Snow v. Johnston, 197 Ga. 146, 28 S.E.2d 270 (1943) (could not change from armory to funeral home); City of Lynn v. Deam, 324 Mass. 607, 87 N.E.2d 849 (1949) (can't change from dance hall to restaurant); Crompton \& Co. v. Sea Girt, 1 N.J. Super. 607, 63 A.2d 834 (1949) (storage of boats and autos does not establish use for storage of food) ; Kensington Realty Holding Co. v. Jersey City, 118 N.J.L. 114, 191 Atl. 787 (Sup. Ct. 1937), aff'd, 119 N.J.L. 338, 196 Atl. 691 (1938) (use for doctor's office and for tea room could not establish use for funeral parlor).

34. See Application of Braunsdorf, 111 N.Y.S.2d 507, 511 (Sup. Ct. 1952) (attempt to change from manufacture of organ supplies to manufacture of syrup).

35. See Botz v. Garrett, 236 Mo. App. 566, 159 S.W.2d 367 (1942).

36. The Philadelphia zoning ordinance says that a "use shall not be changed to a use designated for a district having less restictive regulations." PhILAderpHIA Zoning Ordinance $\$ 4(3)$. Ordinances of the City of Philadelphia 274 (1933), as amended through 1952. The implication is that it may be changed to a use of a higher classification. 
fruitless efforts to obtain a permit are not sufficient.37 But where the owner has obtained a valid permit and has either done substantial constructing or incurred substantial liabilities, the general rule is that a "vested right" to such use is established.38 A minority of cases, relying on the alleged prospective nature of zoning, have indicated that mere issuance of a valid permit without construction creates an existing use. ${ }^{39}$ Under the prevailing view, acts insignificant in themselves ${ }^{40}$ or those trifling in respect to the final $\operatorname{cost}^{41}$ are not sufficient to raise a use.

A peculiar problem in defining an existing use arises when sufficient construction to establish a use has taken place while a zoning ordinance is under consideration, and the use by virtue of this ordinance becomes nonconforming. Some cases say that here a property owner acts at his peril and cannot qualify for an exemption, ${ }^{42}$ although at least one decision has been to the contrary. ${ }^{43}$ In this situation many factors probably enter into the final determination. Did the individual act in good faith, or was he merely trying to "beat" the ordinance? Did the municipality delay an unusually long time 44 and thus present the builder with the choice of either postponing construction indefinitely or "taking a chance" with the zoning ordinance? Was the fact that zoning was under consideration

37. Taub v. McElligott, 246 App. Div. 729, 283 N.Y. Supp. 665 (2d Dep't 1935) ; Gheen v. Mencer, 52 Pa. D. \& C. 422 (1945).

38. Pelham View Apts. v. Switzer, 130 Misc. 545, 224 N.Y. Supp. 56 (Sup. Ct. 1927) (paid for architect's services and excavation; court also emphasizes payment of purchase price in reliance on right to build). Wickstrom v. City of Laramie, 37 Wyo. 389, 262 Pac. 22 (1927) (garage half built before permit revoked). Compare New Britain v. Kilbourne, 109 Conn. 422, 147 At1. 124 (1929) where ordinance allowed completion of structures if construction were begun within 90 days. Defendant started grading, filling ravine and building a culvert. The court held that this was sufficient and added that the exception to the ordinance "fairly seeks to avoid the unjust imposition of loss upon those who have in good faith and in reliance upon the act of the city thus invested their money and labor in building operations." Id. at 427,147 Atl. at 125 .

39. London v. Robinson, 94 Cal. App. 774, 271 Pac. 921 (1928) (court said that a section of the ordinance clearly exempted cases where permits already issued, but also indicated that their rule of construction was that the ordinance will not revoke permits unless it specifically so states). Compare Brown v. Grant, 2 S.W.2d 285, 287 (Tex. Civ. App. 1928) (buildings were "wellnigh completed" before ordinance took effect, although the court indicated that a permit is a contract which cannot be breached).

40. McCurley v. El Reno, 138 Okla. 92, 280 Pac. 467 (1929) (four or five men did a half day's work on the foundation which was not enough). But cf. In re Appeal of Supply Co., 202 N.C. 496, 163 S.E. 462 (1932) (placing building materials on premises with intent to build is sufficient).

41. Brady v. Keene, 90 N.H. 99, 4 A.2d 685 (1939) (entering into leasing agreement and cutting some shrubbery not enough).

42. Colby v. Board of Adjus't, 81 Colo. 344, 255 Pac. 443 (1927) (knew of impending ordinance); Dallas v. Meserole, 155 S.W.2d 1019 (Tex. Civ. App. 1941) (what construction was done appears to have been minor).

43. Clinton v. Ross, 226 N.C. 682, 40 S.E.2d 593 (1946) (construction between adoption and effective date of ordinance).

44. See Mongiello Bros., Inc. v. Board of Comm'rs, 10 N.J. Misc. 131, 158 At1. 325 (Sup. Ct. 1932) (court ordered issue of permit because of the delay); Deerfield Realty Co. v. Hague, 6 N.J. Misc. 637, 151 At1. 373 (Sup. Ct. 1930); Atlas v. Dick, 192 Misc. 843, 81 N.Y.S.2d 126 (Sup. Ct. 1948). 
given public notice? Possibly the problem can be alleviated by a publicized legislative resolution to the effect that a zoning ordinance is under consideration. ${ }^{45}$

When the existing use was undertaken in violation of a law, another difficult problem may be presented. If, when the use was instituted, the owner knowingly violated the zoning or some other law, the courts have no difficulty in requiring discontinuance of the use. ${ }^{46}$ This result seems justified, since one who intentionally violates the law should not be able thereby to defeat the purposes of zoning. When, however, the unlawful construction results from an error by the building inspector rather than being an intentional violation by the owner, a decision is more difficult. One answer is to say that a valid permit, once issued by an authorized agent acting within his authority, confers the right to a use if acted upon. ${ }^{47}$ The opposite result is occasionally reached on the theory that the city is not estopped from enforcing its zoning because of acts of its officials. ${ }^{48}$ It is difficult to see how property owners in these cases are in a position any different from that of the owner of a use which existed prior to the zoning restriction.

Ordinarily in defining a nonconforming use, no distinction is made as to whether or not the land has been improved. It has been held that the storage of lumber on land by a lumber company constituted a use within the nonconforming provision. ${ }^{49}$ The result has been the same when the land is used annually for a carnival. ${ }^{50}$ In the latter case, the court maintained that the nonconforming use section of the law was directed at the use of land and not the occupancy of it.

Extension of Use and Alteration of Facilities.-A necessary corollary to the definition and description of the nonconforming use is the question of the extent of the rights obtained once the use itself is established. From early in the history of zoning it has been recognized that a legitimate method whereby the nonconforming use can be eliminated is to limit its

45. In McCurley v. El Reno, 138 Okla. 92, 280 Pac. 467 (1929) the court enforced a temporary zoning ordinance which for one year prevented, inter alia, construction of business buildings in areas designated residential. The ordinance was held not subject to the statutorily prescribed procedure for zoning enactments. For a similar holding see Lima v. Woodruff, 107 Cal. App. 285, 290 Pac. 480 (1930).

46. Wilkins v. San Bernardino, 162 P.2d 711 (Cal. 1945) ; aff'd, 29 Cal. 2d 332, 175 P.2d 542 (1946) (zoning law); Larson v. Howland, 108 N.Y.S.2d 231 (Sup. Ct. 1951) (restrictive covenant); Heimerle v. Bronxville, 168 Misc. 783, 5 N.Y.S.2d 1002 (Sup. Ct. 1938) (no permit); Town of Ramapo v. Bockar, 151 Misc. 613, 273 N.Y. Supp. 452 (Sup. Ct. 1934) (conservation law); Kane v. Lapre, 69 R.I. 330, 33 A.2d 218 (1943) (had knowingly violated statute ten years before any action was taken); Scott v. Champion Bldg. Co., 28 S.W.2d 178 (Tex. Civ. App. 1930) (zoning law).

47. Village of Attica v. Day, 134 Misc. 882, 236 N.Y. Supp. 607 (Sup. Ct. 1929), aff'd, 230 App. Div. 776, 243 N.Y. Supp. 915 (4th Dep't 1930).

48. Corpus Christi v. Jones, 144 S.W.2d 388 (Tex. Civ. App. 1940).

49. Durkin Lumber Co. v. Fitzsimmons, 106 N.J.L. 183, 147 At1. 555 (1929).

50. Civic Ass'n of Dearborn v. Horowitz, 318 Mich. 333, 28 N.W.2d 97 (1947). 
expansion and alteration of its facilities. ${ }^{51}$ Consequently, some ordinances state that a nonconforming use may not be extended or the premises altered, ${ }^{52}$ or that its extension is limited to a certain fixed percentage of area. ${ }^{53}$ Two theories have developed as to what limitations may be cast about the extension of the existing use. The first is that the use once instituted may be restricted to the boundaries of the original lot, but within this sphere must be allowed to increase by natural expansion. ${ }^{54}$ The narrower theory is that the use as of the date of zoning enactment describes the exact limits. ${ }^{55}$ The influence of this latter theory is manifest in the general rules, sometimes legislatively imposed, that existing nonconforming uses may not be extended by new buildings, ${ }^{56}$ by additions to existing buildings, ${ }^{57}$ by reconstruction or replacement of old buildings, ${ }^{58}$ or by changing the use. ${ }^{59}$ On the other hand, Pennsylvania has allowed the construction of a concrete warehouse for the storage of lumber which had formerly been kept in the open, on the theory that such additions, made to provide for natural expansion and increased trade, cannot be prevented unless detrimental to the health, welfare, and morals of the com-

51. See Note, $35 V_{\text {A. }}$ L. Rev. 348, 353 n.35 (1949). Bassett says: "A nonconforming building cannot be enlarged as a matter of right." BASSETT, ZoNING 109 (1936).

52. E.g., Dayton, Ohio Zoning Ordinance $\$ 210$ cited in Note, 35 VA. L. REv. 348,349 (1949).

53. The Philadelphia zoning ordinance limits extension of a nonconforming use in a building to $25 \%$ of the area of the building at the time of the ordinance. Philadelphia Zoning Ordinance $\$ 4(6)$, Ordinances of the City of PhiladeiPHIA 275 (1933), as amended through 1952.

54. E.g., In re Gilfillan's Permit, 291 Pa. 358, 140 Atl. 136 (1927).

55. E.g., Billerica v. Quinn, 320 Mass. 687, 71 N.E.2d 235 (1947) (stripping the top soil) ; People v. Gerus, 69 N.Y.S.2d 283 (County Ct. 1942) (sand pit).

56. Yuba City v. Cherniavsky, 117 Cal. App. 568, 4 P.2d 299 (1931) ; Connors v. Burlington, 325 Mass. 494, 91 N.E.2d 212 (1950); Inspector of Bldgs. v. Murphy, 320 Mass. 207, 68 N.E.2d 918 (1946) ; Hyams v. Amchir, 57 N.Y.S.2d 77 (Sup. Ct. 1945).

57. Rehfeld v. San Francisco, 218 Cal. 83, 21 P.2d 419 (1933); Knox v. Baltimore, 180 Md. 88, 23 A.2d 15 (1941) ; Green v. Board of Comm'rs, 131 N.J.L. 336, 36 A.2d 610 (1944); Meixner v. Board of Adjus't, 131 N.J.L. 599, 37 A.2d 678 (1944); Burmore Co. v. Smith, 124 N.J.L. 541, 12 A.2d 353 (1940); Taft v. Zoning Bd. of Review, 75 R.I. 117, 64 A.2d 200 (1949).

58. Thayer v. Board of App., 114 Conn. 15, 157 Atl. 273 (1931) ; Price v. Ackman, 345 Ill. App. 1, 102 N.E.2d 194 (1951); Colati v. Jirout, 186 Md. 652, 47 A.2d 613 (1946) ; Sitgreaves v. Board of Adjus't, 136 N.J.L. 21, 54 A.2d 451 (Sup. Ct. 1947); Cole v. Battle Creek, 298 Mich. 98, 298 N.W. 466 (1941); DeVito v. Pearsall, 115 N.J.L. 323, 180 Atl. 202 (Sup. Ct. 1935).

59. Moore v. Lexington, $309 \mathrm{Ky} .671,218$ S.W.2d 7 (1948) (ordinance which prevented plaintiff from converting garage apartment for servants into efficiency apartment for renting, upheld) ; Lexington v. Bean, 272 Mass. 547, 172 N.E. 867 (1930) (change from repair shop for owner's fleet of trucks to a commercial repair shop is substantially different and not allowed under the ordinance); People v. Giorgi, 16 N.Y.S.2d 923 (County Ct. 1939) (from use incident to general contracting to manufacture of cement blocks not allowed) ; Shields v. Spokane School Dist., 31 Wash. 2d 247, 196 P.2d 352 (1948) (from elementary school to trade school). 
munity. ${ }^{60}$ Similarly, in a case arising under a New York City ordinance the cementing of an entire lot and the installation of storage tanks and pumps for a gas station, where previously a stable had stood, were permitted because the ordinance restricted the alteration of buildings but not of premises. ${ }^{61}$ These latter decisions illustrate the results which can stem from the application of a philosophy of natural expansion.

The application of the theories is clearer when the attempted change involves internal modifications or deletions from the buildings or an increase in area or volume of the use. Apparently under either the strict limitation or the natural expansion doctrine, insubstantial renovations or extensions are permissible, ${ }^{62}$ although even here strict limitations as to cubic footage have sometimes been imposed. ${ }^{63}$ When the existing use involves unimproved land, such as is the case with extraction, under the natural expansion theory the whole lot is considered to be in use from the beginning and operations may be extended accordingly. ${ }^{64}$ The strict limitation concept goes to the other extreme, saying that a use must be limited to the extent of use at the time of ordinance adoption or it cannot be preserved. ${ }^{65}$ An attempt by the nonconforming user to increase the volume of his business over that existing at the date of ordinance is usually condoned on the theory that an increase in magnitude, no matter how great, is not a prohibited extension. ${ }^{6 B}$ In one case a court recognized that a

60. In re Gilfillan's Permit, 291 Pa. 358, 140 Atl. 136 (1927). See also Humphreys v. Stuart Realty Corp., $364 \mathrm{~Pa} .616,73$ A.2d 407 (1950) (storage capacity for gasoline increased from 100,000 gallons to 224,000 gallons by addition of new storage tanks); Kellman v. McShain, 369 Pa. 14, 85 A.2d 32 (1951) (could replace by a solid roof a roof which had had a ten foot square opening and which had been destroyed by fire).

61. 440 E. 1022 St. Corp. v. Murdock, 285 N.Y. 298, 34 N.E.2d 329 (1941).

62. Paul v. Scituate, 301 Mass. 365, 17 N.E.2d 193 (1938) (construction of additional room on restaurant) ; Page v. Grosse Point, 279 Mich. 254, 271 N.W. 826 (1937) (installation of new front on store); Iane v. Bigelow, 135 N.J.L. 195, 50 A.2d 638 (1947) (removal of 35 feet of fronting of building to change auto service station into modern drive-in service station) ; Davis Appeal, $367 \mathrm{~Pa}, 340,80$ A.2d 789 (1951) (internal alterations to increase number of apartments from three to four).

63. State ex rel. Hochfelder v. New Orleans, 171 La. 1053, 132 So. 786 (1931) (ordinance which was interpreted to prevent any increase in square footage or cubical contents enforced so as to prevent any increase in store space by removal of partition). But ef. People ex rel. Wohl v. Leo, 109 Misc. 448, 178 N.Y. Supp. 851 (Sup. Ct. 1919) (whole building may be used for purpose for which it was designed although only half was so used at the time the ordinance was passed).

64. Lamb v. A. D. McKee, Inc., 10 N.J. Misc. 649, 160 Atl. 563 (Sup. Ct. 1935); Cheswick Borough v. Bechman, $352 \mathrm{~Pa} .79,42$ A.2d 60 (1945).

65. Edmonds v. Board of Sup'rs, 236 P.2d 646 (Cal. 1951) (number of trailers in trailer camp) ; Billerica v. Quinn, 320 Mass. 687, 71 N.E.2d 235 (1947) (stripping of top soil); People v. Gerus, 69 N.Y.S.2d 283 (County Ct. 1942) (sand pit).

66. Green v. Garrett, 192 Md. 52, 63 A.2d 326 (1949) (from use for professional football and one professional baseball game to use for professional baseball for a considerable part of the year at night as well as during the day); Cochran v. Roemer, 287 Mass. 500, 192 N.E. 58 (1934) (from small retail coal and coke business using two or three trucks to a wholesale fuel business with many new structures and as many as 28 trucks. Ordinance allowed enlargement and alteration so long as not detrimental to the community); People v. Perkins, 282 N.Y. 329, 26 N.E.2d 278 (1940) (increase in volume of flower, vegetable and fruit business with more extensive use of lot). Cf. Marcus v. Marmaroneck, 283 N.Y. 325, 28 N.E.2d 856 
business may increase and the manner of operation change so much that in effect the nature of the use is changed. ${ }^{67}$

Discontinuance.-A common method for extinguishing a nonconforming use is to require by ordinance that if the use is discontinued, it may not thereafter be resumed. ${ }^{68}$ The rationale behind this rule is that the once great burden of conformance is no longer present when the owner, by his own initiative, has ceased to exploit the use. ${ }^{69}$ Although probably all would agree that the use is terminated if the building constituting the use collapses from age, ${ }^{70}$ courts in applying the provision in any situation short of this have made it difficult to show discontinuance. The doctrine is that discontinuance equals abandonment and abandonment requires a voluntary, completed, affirmative act on the part of the owner. ${ }^{71}$ It requires the concurrence of an intent to abandon and some overt act or failure to act which implies abandonment. ${ }^{72}$ The elusive nature of this doctrine precludes any absolute statement as to what will or will not amount to abandonment. Since intent is considered important, probably the mere passage of time will not amount to abandonment, but as the period of nonuse grows it may become easier to demonstrate the intent to abandon. One factor given weight in determining the intent is whether the building continues to be adaptable for the use. ${ }^{73}$ The intent necessary to indicate abandon-

(1940), reversing, 258 App. Div. 328, 16 N.Y.S.2d 626 (2d Dep't 1940) (Lower court permitted large increase in dining and refreshment facilities at beach club. Court of appeals reversed on the ground that the cost of alterations was beyond limit set by ordinance). In Firth v. Scherzberg, $366 \mathrm{~Pa}$. 443, 77 A.2d 443 (1951), the use had increased to such a magnitude as to be enjoinable as a nuisance at night, but still was allowed to continue as a nonconforming use in the day-time.

67. Marblehead v. Rosenthal, 316 Mass. 124, 55 N.E.2d 13 (1944) (from dry cleaning establishment, where most work sent out, to "industrial establishment," where most work done on the premises).

68. "No building or premises where a nonconforming use is discontinued for more than two years . . Shall again be devoted to any use that is prohibited in such district." Dayton, Ohio, Zoning Ordinance $\$ 210$ cited in 35 VA. L. REv. 348, 349 (1949): The ordinance may also take the form that once the use is changed to one of a higher classification or to a conforming use it may not thereafter be changed to a use of a lower classification. See ordinance cited in Collingsdale v. Mager, 32 Del. County 305 ( $\mathrm{Pa}$. 1944).

69. "The accepted method of accomplishing the ultimate object [of zoning] is that, while the alien use is permitted to continue until some change is made or contemplated, thereupon, so far as is expedient, advantage is taken of this fact to compel a lessening or suppression of the nonconformity." Darien v. Webb, 115 Conn. 581, 585, 162 At1. 690, 692 (1932).

70. Fidelity Trust Co. v. Downing, 224 Ind. 457, 68 N.E.2d 789 (1946).

71. Binghamton v. Gartell, 275 App. Div. 457, 90 N.Y.S.2d 556 (3d Dep't 1949); State ex rel. Shaetz v. Manders, 206 Wis. 121, 238 N.W. 835 (1931).

72. Wood v. District of Columbia, 39 A.2d 67 (D.C. Mun. App. 1944) ; Douglas v. Melrose Park, 389 I11. 98, 58 N.E.2d 864 (1945); People ex rel. Delgado v. Morris, 334 Ill. App. 557, 79 N.E.2d 839 (1948); Highland Park v. Marshall, 235 S.W.2d 658 (Tex. Civ. Ápp. 1950). See also Longo v. Eilers, 196 Misc. 909, 93 N.Y.S.2d 517 (Sup. Ct. 1949) where dilapidated condition of grandstand, failure to pay taxes and six year vacancy were held to show voluntary relinquishment of a known right.

73. See Haller Baking Co.'s App., 295 Pa. 257, i45 Atl. 77 (1928) ; Marshak v. Long Beach, 81 N.Y.S.2d 74 (Sup. Ct. 1948). 
ment is most readily shown by a conversion to another use, ${ }^{\mathbf{7 4}}$ but lesser acts may sometimes be sufficient. ${ }^{75}$

An interesting problem arises when the use has ceased as the result of some force beyond the control of the owner, such as depression, war, or fire, and other "natural" causes. Since the general doctrine requires that the abandonment be voluntary, the common result in these cases is that the owner may continue his nonconforming use whether it requires reconstruction ${ }^{76}$ or not. ${ }^{77}$ But here, too, he may possibly lose his right if there is evidence of an intent to abandon ${ }^{78}$ or, if the ordinance so provides, he fails to rebuild a destroyed building within a specified time. ${ }^{79}$

Amortization.-A refinement of discontinuance as a method of destroying nonconforming uses is amortization, whereby within a specified time nonconforming uses must be discontinued. The theory seems to be that it is not unreasonable to require the nonconforming user to cease operations at the end of the time since during the period of grace he has a monopolistic position which, if properly exploited, sufficiently compensates him for the eventual property deprivation. ${ }^{80}$ Although amortization appears to be a highly desirable method of eliminating the uses, the number of cases on the subject indicates that it has been used infrequently. Twentyfour years ago the Louisiana court, using a theory of nuisance law, sustained an ordinance with a one year amortization provision. ${ }^{81}$ More recently a Tallahassee ordinance, which required the removal from a residential district within a period of ten years of all automobile service sta-

74. Knickerbocker Ice Co. v. Sprague, 4 F. Supp. 499 (S.D.N.Y. 1933) ; Branch v. Powers, 210 Ark. 836, 197 S.W.2d 928 (1946) ; In re Auditorium Inc., 84 A.2d 598 (Del. Super. 1951) ; Montclair v. Bryan, 16 N.J. Super. 535, 85 A.2d 231 (1951); Berdan v. Patterson, 137 N.J.L. 286, 62 A.2d 680 (Sup. Ct. 1948); Chipolone v. Clifton, 137 N.J.L. 307, 59 A.2d 815 (Sup. Ct. 1948). Minor changes in use will be all right. See Ewing v. Braun, 196 So. 571 (La. 1940).

75. See Francisco v. Colombus, 31 N.E.2d 236 (Ohio 1937) (acts outweighed alleged intent when owner built new plant and removed most machinery from old); State v. Casper, 5 N.J. Super. 150, 68 A.2d 545 (1949) (ejecting roomers and renting for a private home).

76. Brous v. Hempstead, 272 App. Div. 31, 69 N.Y.S.2d 258 (2d Dep't 1947) (complete destruction by hurricane); Navin v. Early, 56 N.Y.S.2d 346 (Sup. Ct. 1945) (destruction by fire less than $75 \%$ under an ordinance which said that reconstruction permit may be issued if less than $75 \%$ loss).

77. Haulenbeek v. Allenhurst, 136 N.J.L. 557, 57 A.2d 52 (1947) (depression then use by the army); People v. Emigrant Industrial Sav. Bank, 261 App. Div. 402, 25 N.Y.S.2d 605 (1st Dep't 1941) (could continue as nonconforming parking lot where destroyed building was a nonconforming garage); State ex rel. Míorehouse v. Hunt, 235 Wis. 358, 291 N.W. 745 (1940) (fraternity house leased as private home during depression).

78. Curtis-Wright Export v. Garden City, 185 Misc. 508, 57 N.Y.S.2d 377 (Sup. Ct. 1945) (retention of some employees and records at the plant and use of part of the plant to produce income negated intent to abandon although most of plant had been shut down for eight years and most machinery removed).

79. E.g., Palazzola v. Gulfport, 211 Miss. 737, 52 So.2d 611 (1951).

80 See Note, 9 U. of CHI. L. Rev. 477, 485-6 (1942).

81. State ex rel. Dema Realty Co. v. McDonald, 168 La. 172,121 So. 613 (1929), cert. denied, 280 U.S. 556 (1929). See also State ex rel. Dema Realty Co. v. Jacoby, 168 La. 752, 123 So. 314 (1929). 
tions, was held by the Fifth Circuit to be a reasonable exercise of the police power. ${ }^{82}$ These appear to be the only cases; but, since several large cities have recently adopted amortization provisions, 83 the popularity of this method for eliminating nonconforming uses may be on the increase. An impediment in some states will be the enabling statutes which specifically protect nonconforming uses. Since amortization operates to destroy these uses, prior repeal of the protective provisions is probably necessary.

\section{Rationale of the Doctrine}

The basic doctrine in the law of nonconforming uses is that zoning, as distinguished from nuisance law, cannot operate retroactively. Judicial opinions sanction this doctrine by pointing out that the destruction of existing uses places such a great burden on a few individuals that it is not justified in the absence of absolute public necessity. Seldom do the courts go further in explaining why uses are or should be protected.

Zoning as it affects every piece of property is to some extent retroactive in that it applies to land already owned at the time of the ordinance and the effect of zoning restrictions may be to depreciate sharply the value of a particular plot of land. ${ }^{84}$ An unusual example of this may be seen in Euclid v. Ambler Realty Co.,85 the leading case upholding zoning as a legitimate exercise of the non-compensating police power. Here the Supreme Court of the United States sustained zoning restrictions on vacant land directly in the path of Cleveland's industrial development with the effect that value was reduced from $\$ 10,000$ to $\$ 2,500$ per acre. ${ }^{86}$ Although in the ordinary situation the effect is not nearly so drastic, the case serves to highlight the possibility of loss when the use of land is restricted. Furthermore, the cases which require substantial construction before a use in a structure may be established do not always operate to prevent economic loss. The rule may put to naught substantial expenses merely because they were incurred in preparation and investigation rather than in construction. ${ }^{87}$

From a comparison of Jones v. City of Los Angeles 88 and Euclid, and with a view of the substantial construction doctrine in action, one can

82. Standard Oil Co. v. Tallahassee, 183 F.2d 410 (5th Cir. 1950).

83. See [1951] WIS. L. REv. 685, 691.

84. Noel, Retroactive Zoning and Nuisances, 41 Cor. L. Rev. 457, 458 (1941). Note that an important constituent of market value of land is the land's potentiai uses.

85. 272 U.S. 365 (1926).

86. $I d$. at 384 .

87. County Comm'rs v. Ward, 186 Md. 330, 46 A.2d 684 (1946) (several thousand dollars spent grading and landscaping). Cf. West Bros. Brick Co. v. Alexandria, 169 Va. 271, 192 S.E. 881 (1937) (clay company paid premium on basis of known clay deposits and then was prevented from extracting the clay). Contra: Rosenberg v. Whitefish Bay, 199 Wis. 214, 225 N.W. 838 (1929) (erection of nonconforming building permitted where obligations incurred for architect's services and travel expenses totaled about $\$ 9000)$.

88. See note 8 supra. 
see that the economic hardship inherent in retroactivity cannot be relied on as the sole reason for protecting existing nonconforming uses. Other grounds must be put forth to explain why courts have been unanimous in condemning the Jones situation (existing use) and sustaining the Euclid case (potential use).

Effect on Present Ozoner.-First it must be recognized that zoning is a collection of restrictions and every restriction means a possible loss to someone; it is only in the exceptional case where the loss is especially great that protection should be afforded. ${ }^{89}$ The easiest and most workable place to draw a line is at the existing use, especially if the use embodies substantial improvement on the land. An obvious difficulty here, however, is that convenience of administration, in itself, is a weak basis for a rule.

A second reason for drawing the existing-potential dichotomy concerns, in particular, going businesses. Since there are few if any zones from which private residences are prohibited, probably the bulk of nonconforming use cases concern business properties. The enforced removal or discontinuance of these uses will involve an interruption or cessation of business with the resultant loss of good will and trade. It is not a sufficient answer to this problem to say that the individual need merely relocate and resume operations, for, especially in older municipalities, space may not be available, and in addition, location is an important factor in good will.

Effect on economic investment.-Any adverse effect on the present owner of land will, of course, discourage future investment. This is another way of explaining the protection given existing uses. The law of zoning should be designed to protect the reasonable expectations of persons who plan to enter business or make improvements on property. The possibility that the municipality could by zoning force removal of installations or cessation of business might serve to deter such investors. The danger of deterring investment was particularly great when zoning in its early history was experiencing a sharp rise in popularity, with urban investors anxiously watching its approach to their community. The problem must still be faced today in communities which do not yet have a comprehensive zoning enactment. Furthermore, even in municipalities where zoning is established, there is always the possibility that the city will change the zoning classification. Reclassification is most likely to occur, if at all, along the dividing lines between zones and in zones which are in a state of transition.

The existing-potential line, then, serves to assure individual landowners that the material investments which they make will not be dissolved by the government without compensation unless the use constitutes a nuisance. Furthermore, the general requirements of zoning which demand

89. See text at and preceding note 12 supra. 
that in classifying an area the city consider the present nature of that area give added assurance to improvers of land.90

To state the reasonable expectations rationale differently, the protection of existing uses protects the increase in value of property caused by owner-made improvements and does not protect the value increment caused by forces beyond the control and efforts of any particular holder of property. Thus owners who make use of, or improve, land are protected while the holder of unused land is not. A number of considerations serve to justify this distinction. Effective zoning requires a policy of enforcing restrictions as fully as possible. Since much unused land is held merely as a speculative venture, to deny special protection to the owners of such land would not necessarily frustrate their primary purpose, i.e., to sell the land at a higher price; in fact, future zoning restrictions may be a factor upon which they are speculating. In addition, the dominant public policy of encouraging the use of land helps to explain the preference given to one who develops realty, as opposed to one whose land is making no contribution to the public wealth. This may be the explanation of the Supreme Court's refusal to condemn the extraordinary effect of the ordinance in the Euclid case.

Prevention of Economic Waste.-The foregoing reasons justify the accepted distinction becatuse it allows zoning to operate with relative freedom and still affords protection to individuals in their capacity as private owners or potential investors in land improvements and business. But another possible approach is to consider society's interest in the existing nonconforming use, i.e., that forced destruction will often result in economic waste. Although this reason justifies the legislative judgment that existing uses should be protected, it should also aid courts in interpreting and applying the legislative rule. Avoidance of economic waste supplies, in addition, an argument against indiscriminate use of the power of eminent domain. In the case of highly specialized buildings the public benefit of discontinuing their use by eminent domain would be trifling compared to the resultant waste. Even where the improvements are not so specialized and could be readily converted to a conforming use, the reconstruction necessary to relocate the activity may be quite wasteful. A further aspect of economic waste concerns extraction operations, such as mining and quarrying, which must be confined to the places where the materials can be found. Here, especially if the commodity is essential, there may be good reason to allow continuance, to liberalize the rules against expansion and even to permit operation of quarries not yet opened in order to utilize the minerals. ${ }^{91}$

90. See text at notes $3,4,6,7$ supra.

91. The Philadelphia zoning ordinance allows the Zoning Board of Adjustment to permit opening and/or operating of quarries in any district. PHILADELPHIA Zoning Ordinance $\$ 26(9)$, Ordinances of the City of Philadelphia 335 (1933), as amended through 1952. 'Compare West Bros. Brick Co. v. Alexandria, 169 Va. 271, 192 S.E. 881 (1937), where clay company which had paid a premium for land with known clay deposits was denied under ordinance passed subsequent to purchase of land, right to extract clay. 


\section{Criticism of Present Law}

Consideration of both the objectives of zoning and the submitted reasons for protecting existing uses poses the problem as one of developing or preserving an ideally planned community by preventing or eliminating undesired uses in certain areas without (1) imposing undue hardship on individuals; (2) unreasonably deterring investment in business, or in land improvements; (3) or causing unnecessary economic waste. There remains the task of analyzing present law in terms of this basic conflict.

Defining the Nonconforming Use.-The common prerequisite for protection as a nonconforming use is that the use be a going activity; where this requirement is met, a balancing of the public interest against the private interest leads to the conclusion that usually protection is justifiable. Where the activity involves the use of land improvements, discontinuance will ordinarily result in economic waste as well as severe personal loss with the concurrent deterrence of economic investment. This result, of course, follows only if the improvements involved are not readily convertible to a conforming use. With uses operated on substantially unimproved land, such as parking lots and open storage, the balance is more favorable to the public interest than it is where there are improvements. Here any investment which the owner has is, in all likelihood, considerably less than that of owners with improvements. Furthermore, there is little chance of economic waste on unimproved land. But good will of a going business does attach to a location and the reasonable expectations of users of this land deserve to be considered. An intelligent approach to the definition of the nonconforming use requires that the legislature in the first instance, supplemented by the courts where necessary, consider all such factors in an attempt to balance the basic conflict of interests.

A rule which requires substantial construction before an existing use will be declared also seems, in the light of a weighing of interests, to be justified in most cases. There is no interference with a going business or good will accompanying removal of even substantial construction; however, removal of even insubstantial construction will result in some hardship to the individual and some economic waste. Furthermore, an owner who plans to build may reasonably expect that once construction has started he will be able to complete the improvement and operate it. Yet, in comparison with the results in forcing removal of substantial construction, to destroy insubstantial construction creates relatively little economic waste, personal hardship, and deterrence to investment.

The three objections to destroying nonconforming uses again have relevance in determining how broad the exemption for nonconforming property should be. When an owner desires to change his use it is often because of the compulsion of economic conditions. The factors of going business and good will are, at the time, substantially minimized. But, since the salvage value of improvements will be eliminated in such a case if the owner is required either to continue or to conform, economic hardship and economic waste may occur. Thus, a limitation which permits 
minor changes in the nature of the use seems to be the one most in accord with a balancing of interests. However, since few if any of these objections apply to uses on unimproved land, there may be no impediments to the prohibition of any change of use in that situation.

Unless the owner has acted knowingly or unreasonably, there is no justification for refusing to apply the foregoing analysis to nonconforming uses which come into existence through violations of law. Although the law breacher can hardly be said to have "rightfully" initiated his use, the objections of interference with business and production of economic waste apply also to his case. These factors, in addition to the owner's innocence and the probable infrequency with which the problem will arise, militate against a declaration that the public interest in zoning outweighs the importance of continuing the use.

Extension and Alterations.-To analyze the doctrine of extension one must return again to the basic conflict in zoning which makes necessary the nonconforming use. Certain owners are given an exemption from conformance in order to protect present investment, to encourage future investment and to prevent economic waste. At this point they are in no worse position than the vacant landowner, who receives no exemption, because any possibility of increase in value is speculative in nature. In addition, if the owners are businessmen, they are given the advantage of a monopolistic position in the area. If conversion to a conforming use can be encouraged without interfering with the original reasons for allowing the use, the ultimate goal of zoning can be attained. At the outset, strict limitations on expansion appear to accomplish this result since the owner is given the present use of the premises with the right to exploit a monopoly, but is forced to relocate when his needs increase. The difficulties, however, are that one of the reasonable expectations of a person entering business is that he will be able to expand when necessary, and, also, that economic use of one's existing installations may require occasional expansion. These problems are especially evident where the use is an extraction operation, for here the exercise of the use is impractical without the right to expand. In short, a hard and fast rule is undesirable; a strict limitation rule with provision for the granting of an exception by the zoning board in the necessary cases may be the most reasonable solution.

Discontinuance.-In the doctrine of discontinuance is found the strongest evidence of a desire on the part of courts to protect the nonconforming user. Protection is accomplished mainly by equating discontinuance with abandonment and then applying the narrow rules for abandonment of real property to the rights of a nonconforming user. This analysis omits consideration of the fact that the community interest in eventual dissolution of nonconforming uses is greater than the community interest in the abandonment of real property. Recognition of an intent to continue as a force sufficient to preserve a nonconforming use ${ }^{92}$ may

92. See text at note 72 supra. 
often be unnecessary to avoid either personal loss or deterrence of investment activity. Adequate protection appears to inhere in recent decisions which have recognized that a city may by ordinance make mere non-use for a certain period of time sufficient to extinguish the right so long as the stipulated time is reasonable. ${ }^{93}$ Economic waste, although less of a factor when the use has been discontinued, militates against such a result, because of the unreasonableness of requiring the destruction of some specialized buildings that still have use value. Where a building has been destroyed by an act of God, no economic waste and little loss to the individual would follow from forbidding reconstruction; public interest in enforcing zoning would ordinarily outweigh the loss of good will from forcing the owner to rebuild elsewhere.

Amortization.-Although, prima facie, amortization appears to satisfy most of the objections to destroying nonconforming uses, there is the difficulty that unless the time period is varied for each type of installation there is a high possibility of economic waste when specialized properties are involved. Otherwise amortization seems to give effect to interests of the community without running afoul of the principal reasons for allowing nonconforming uses to exist and continue.

\section{CoNCLUSION}

The ultimate object of zoning is the development of a planned community which theoretically will benefit the public as a whole. As has been demonstrated, however, this object cannot and should not be achieved indiscriminately at the expense of the owner of the nonconforming use. The purpose of this Note has been to describe present zoning law, to attempt a logical rationalization for the protection of nonconforming uses and to develop an approach whereby the determination of future cases may be facilitated. Prevention of personal loss, encouragement of future investment, and prevention of economic waste are all factors to be considered in opposition to the desire for a planned community. The definition of the existing use should be in terms of a resolution of this conflict rather than an attempt to discover what is a use and whether or not it exists. When the question shifts to one of extension or discontinuance the inquiry should be the same. Always it should be remembered that zoning law is necessary to dissolve an undesirable use only because the use was not sufficiently noxious to be controllable under nuisance law or to command the city to expend funds under the power of eminent domain. This being the case, the need for a destructive element in zoning is considerably lessened. Yet, since the existence of nonconforming uses is inconsistent with the ultimate goal of zoning, there should be no hesitation in destroying these developmental inconsistencies as soon as the reasons for their protection have ceased to exist.

93. Berkman v. Board of App., 135 Conn. 393, 64 A.2d 875 (1949) (ordinance applied to sale of liquor); Franmore Realty Corp. v. LeBourf, 201 Misc. 220, 104 N.Y.S.2d 247 (Sup. Ct. 1951). 